
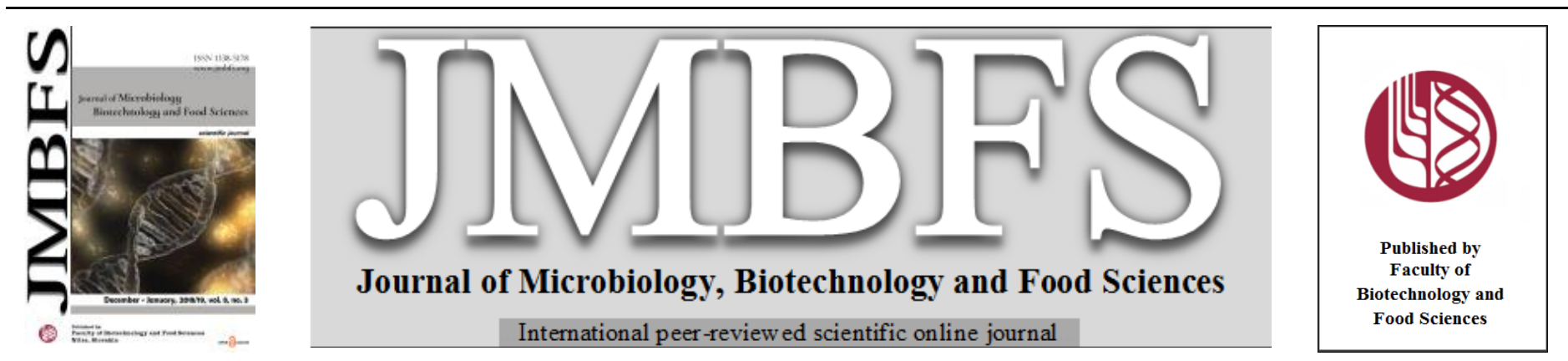

\title{
CEREAL BASED FUNCTIONAL BEVERAGES: A REVIEW
}

\author{
Cheryl G. Fernandes ${ }^{1}$, Sachin K. Sonawane ${ }^{2}$, Arya S. S. ${ }^{{ }^{*}}$

\section{Address(es):} \\ ${ }^{I}$ Food Engineering and Technology Department, Institute of Chemical Technology, NM Parekh Marg, Matunga, Mumbai, India. \\ ${ }^{2}$ Food Science and Technology, School of Biotechnology and Bioinformatics, D. Y. Patil University, Navi Mumbai, India.
}

*Corresponding author: shalu.ghodke@ gmail.com

doi: 10.15414/jmbfs.2018-19.8.3.914-919

\section{ARTICLE INFO}

Received 25. 6. 2018

Revised 26. 9. 2018

Accepted 1.10. 2018

Published 1. 12. 2018

\section{Review}

OPEN $\partial_{\text {ACCESS }}$

\begin{abstract}
Whole grains may be processed efficiently and innovatively to create products that would be considered as healthy. A multigrain functional beverage using whole grains like barley, oats, buckwheat and red rice can be prepared. Multigrains that contain whole grains are rich in vitamins B. complex carbohydrates (starch and fiber), and minerals. The complex carbohydrates, specifically soluble fiber, help in the slow and sustained release of energy whereas the B-vitamins and minerals facilitate metabolism. Whole grains are also plentiful in phenolic compounds which have antioxidant capacities. This review deals with the application of different cereals used in the preparation of beverages.
\end{abstract}

Keywords: Cereals, hydrocolloids, bioactives, multigrain beverages, fermented beverages

\section{INTRODUCTION}

There is a growing interest seen among consumers towards more health conscious and wholesome nutrition. This desire to make food as medicine has created a demand for foods with health benefits also known as functional foods. Whole grains are replete with nutrients and bioactives and there is sufficient scientific evidence that their regular consumption has positive effect on health. Processing multiple grains into a multigrain beverage can be an excellent form of a functional food. The following sections throw a light on the underlying idea of a multigrain functional beverage.

Modern lifestyles along with the changing dietary pattern have led to the increasing precedence of diseases like type 2 diabetes, coronary heart disease, cancer, periodontal disease and obesity. Wholesome foods can help to prevent and treat such problems. Nowadays, consumers view foods not only as a medium for satiety but also as a means of disease prevention and control (Siró et al., 2008). This change in perspective over the years has opened the market to wide range of processed food products having specific health benefits. Such foods have been termed as functional foods. A simple definition of functional foods accepted by most food technologist is "foods and food components that provide a health benefit beyond basic nutrition" (Corbo et al., 2014).

Functional foods should at least be a thorough source of the bioactive components based on which functional claims are made. Bioactives are biologically active substances present in various plant and animal foods that do not provide nutrition but have specific roles to play on physiological functioning and thus have an impact on human health. Bioactive components include dietary fibre, vitamins, minerals, carotenoids, fatty acids, prebiotics, probiotics, phytochemicals, enzymes and antioxidants. Figure 1 illustrates the different functional components or bioactives that can be incorporated in a food or beverage. It is the presence of these bioactives that produce the end effect on the consumers' health.

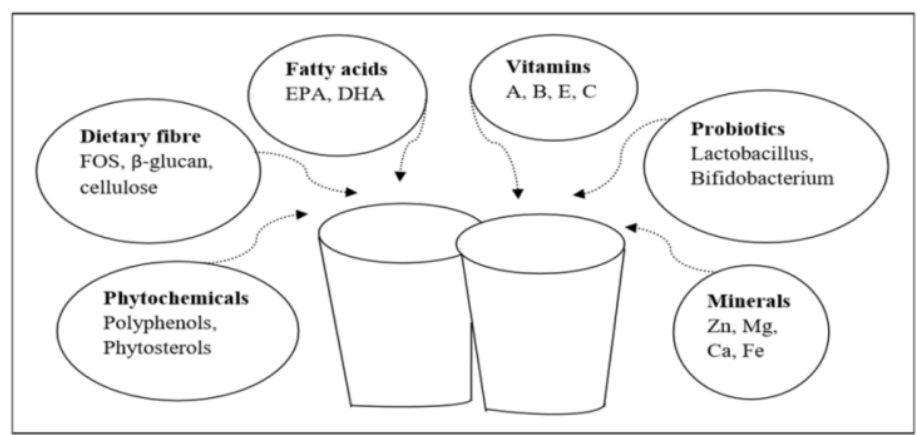

Figure 1 Illustration showing possible functional components present in a beverage

The global functional foods market size was USD 129.39 billion in 2015. The expected growth of the functional food market between 2014-2024 is given in Figure 2 (Functional Foods Market Analysis).

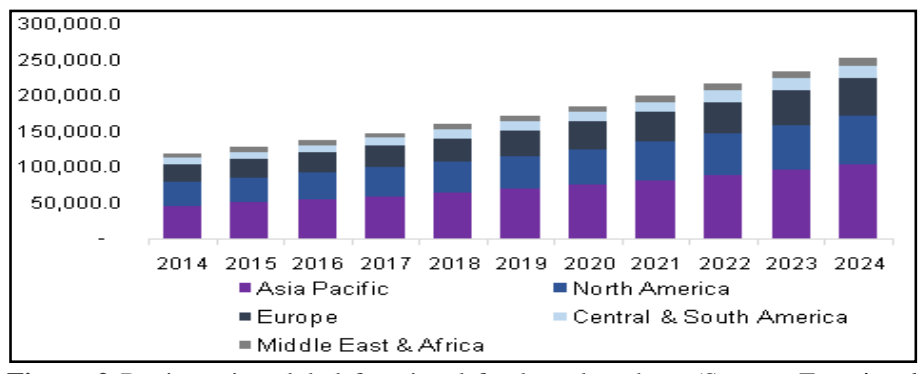

Figure 2 Region wise global functional food market share (Source: Functional Foods Market Analysis)

This shows that there is a steady increase in the global demand of functional food to which the food industry needs to cater. Products containing dietary fiber, vitamins and minerals as the major bioactives occupy largest market space. Maximum number of functional foods manufactured today are dairy based followed by the bakery and cereal based. In India, the functional food and beverage market is at its infancy and was between Rs 46 billion and Rs 49 billion in 2014-15. It was growing at 14-15 per cent (More, 2016). The key trends are functional yoghurt, fortified biscuits and bread, fortified breakfast cereals, 
fortified edible oil and functional gum. A recent trend seen in the Indian beverage market is the rapid growth of two particular sub-categories i.e., functional drinks and juices. All these statistics clearly show the need and scope of functional foods and beverages.

Beverages are the most convenient ready to consume food in the market. Heat treatment, packaging and serving of beverages is relatively easier than solid food. It is also an excellent medium for transport of nutrients and bioactives into the body as well as facilitates their easy absorption (Wootton-Beard and Ryan, 2011). Functional beverages are of several types. Depending on the raw materials used, functional beverages could be classified as dairy based, fruit and vegetable based, legume based, cereal based, coffee and tea. In the present study, multiple grains were selected as the primary raw material of the functional beverage.

A novel use of multigrain in the preparation of products with healthy approaches is reported by Arya et al. (2013). The different multigrains products are developed with healthy approaches are Khakra (Chauhan $\boldsymbol{e t}$ al., 2017), noodles (Kudake et al., 2017, 2018; Muley et al., 2015) and multigrain thalipeeth (Gaikwad and Arya, 2018). Recently Panghal et al. (2018) highlights the application of fruits, cerals and legumes in the development of non dairy probiotic drink with its functional and healthy approach. Thus, the current work emphasizes on developing a functional beverage.

\section{CEREALS AND THEIR ROLE IN HUMAN NUTRITION}

Cereals are staple foods and are a major source of affordable calories throughou the world. They are available throughout the year and are rich in bioactives. Cereals have been used traditionally across the globe, especially in Asia, Africa, South America and parts of Central America. Seven major cereals consumed by humans include rice, rye, maize barley, millets sorghum, and wheat. Besides these, pseudo cereals such as buckwheat, quinoa, and amaranth also contribute significantly to the diet. Cereals and cereal products are an important source of macro and micronutrients, phytochemicals as well as antioxidants (Mckevith, 2004). Cereals and cereal components have the ability to impart prebiotic effects due to presence of water-soluble fiber (Brennan and Cleary, 2005).

\section{HEALTH BENEFITS OF BIOACTIVES PRESENT IN CEREALS}

Phenolic compounds are those having a benzene ring with one or more hydroxyl groups attached to it. They are bitter tasting compounds; present in all plant based foods and affects their color, appearance, taste and oxidative stability. In cereals, they are largely present in the pericarp and can be concentrated by removing the bran. They have antioxidant properties and hence are considered good for health as they can scavenge free radicals in the body known to cause cancers and cardiovascular diseases (Dykes and Rooney, 2007). The popularity of phenolics increases due to their health benefits properties antiapoptosis, antiaging, anticarcinogenic effects and bioactive capacities including antioxidant activity (Hodzic et al., 2009). Although sterol contents of cereals are lower than in oil seeds, cereals can contribute up to $40 \%$ of the daily intake of plant sterols. Plant sterols that include sitosterol, campesterol, stigmasterol, avenasterol, brassicasterols and stanols have the ability to reduce cholesterol absorption (Valsta et al., 2004; Moreau et al., 2002).
Vitamins and minerals are required for the proper functioning of critical biochemical pathways in the human body. They are cofactors of many enzymes and minerals also help in maintaining osmotic pressure. Vitamins B \& E and minerals such as $\mathrm{Ca}, \mathrm{Mg}, \mathrm{Mg}, \mathrm{Fe}, \mathrm{Zn}$ are commonly found in cereals (Hübner and Arendt, 2013)

Dietary fiber is also a very important part of our diet. Dietary fiber is that portion of plant food that cannot be digested by human enzymes, but may be fermented in the large intestine. They are classified as insoluble fiber and soluble fiber based on their solubility in water. Soluble fiber binds with water and forms a ge network while insoluble swells in water and is capable of absorbing water upto 20 times its weight. Cereals are usually insoluble in water whereas fruits and vegetables have greater soluble fractions (Thebaudina et al., 1997). Insoluble fibers include cellulose, hemicellulose and lignins. Soluble fiber on the other hand includes pectins, gums and mucilages. A recent addition to the list of fibers is oligosaccharides such as FOS, GOS and inulin, and resistant starch.

Insoluble fiber increases the intestinal transit time, increase the bulk of faces and hence prevent constipation (Thebaudina $\boldsymbol{e t}$ al., 1997). Cereal fibers appear to be more effective in increasing stool weight as compared to fruit fibers. Soluble fiber is known to affect fat metabolism by binding to cholesterol and reducing its uptake. Soluble fiber also slows down the release of glucose into the bloodstream by forming a viscous layer on the intestinal walls. It increases insulin sensitivity by lowering glycemic response. By virtue of its viscosity soluble fiber increases the gastric emptying time and provides a feeling of fullness for longer duration (Anderson et al.,2009).

Resistant starch is that fraction of starch, which escapes digestion in the small intestine, and may be digested in the large intestine (Sajilata et al., 2006) Multiple studies have revealed that it has physiological functions bear semblance to that both insoluble and soluble fiber in varying degrees (Weisenberger, 2012) Dietary fiber, especially the oligosaccharides serve as excellent prebiotics. They promote the growth of beneficial microorganisms namely, bifidiobacteria and lactobacilli. They improve health of the gut by lowering the $\mathrm{pH}$, reduction of potentially harmful bacteria, producing vitamins, detoxifying potential carcinogens and activating health promoting compounds. Several studies suggest that regular consumption of dietary fiber reduces the incidence of colon cancer (Anderson et al.,2009).

\section{HISTORY OF CEREAL BASED BEVERAGES}

Homo sapiens are said to have appeared 2,00,000 to 1,00,000 years ago. The only beverages consumed by them were water and breast milk. Only about 11,000 years did other beverages such as animal milk, beer, tea, coffee and more recently soft drinks and fruit drinks have entered our diet. Substantial archaeological evidence suggests beer production and consumption between 4000 to $3500 \mathrm{BCE}$ Simultaneously, distilled alcoholic beverages also were developed. Credit has been given to the Sumerians and Egyptians to be the first brewers (Wolf $\boldsymbol{e t}$ al. 2008). Domestication of crops was instrumental in beer making. The inclusion of cereals in the human diet is considered as an important step in human evolution as turning grains into staples required exceptional technical and culinary skills (Harmon, 2009).

Table 1 Traditional fermented cereal based beverages (Altay et al., 2013; Solange et al., 2014; Elaine Marshall, 2012; Kumari et al., 2016)

\begin{tabular}{|c|c|c|}
\hline Name & Description & Place \\
\hline \multicolumn{3}{|l|}{ Africa } \\
\hline Borde & $\begin{array}{l}\text { Beverage made from maize, sorghum, wheat, finger millet and barley by } \\
\text { fermentation }\end{array}$ & Ethiopia \\
\hline Bushera & Beverage based on germinated and fermented sorghum or millet & Uganda \\
\hline Gowé & Fermented beverage based on sorghum or maize or millet & Benin \\
\hline Kunan-Zaki & Beverage made from maize or millet & Nigeria \\
\hline Mahewu & Fermented maize meal and wheat flour based beverage & South Africa \\
\hline Obiolor & Beverage made from sorghum and millet & Nigeria \\
\hline Togwa & Maize flour and finger millet malt fermented beverage & Eastern Africa \\
\hline Mahewu & Fermented maize meal and wheat flour based beverage & South Africa \\
\hline \multicolumn{3}{|c|}{ South America } \\
\hline Acupe & Germinated, fermented and sweetened maize beverage & Venezuela \\
\hline Agua-agria & Non alcoholic beverage based on ground maize and water & Mexico \\
\hline Cachiri & Fermented beverage based on maize, made in clay pots & Brazil \\
\hline Champuz & Fermented beverage from maize or rice & Colombia, Peru \\
\hline Fubá & Beverage made from germinated and fermented maize grains & Brazil \\
\hline Napú & Beverage based on germinated,ground and fermented maize & Peru \\
\hline Pozol & $\begin{array}{l}\text { Acidic beverage based on maize liquor. Balls prepared from fermented dough are } \\
\text { enveloped in banana leaves }\end{array}$ & Mexico \\
\hline \multicolumn{3}{|c|}{ Europe and Asia } \\
\hline Boza & $\begin{array}{l}\text { Fermented malt drink made from maize, millet, wheat or barley. Has thick } \\
\text { consistency with slight acidic, sweet flavour. }\end{array}$ & $\begin{array}{l}\text { Kazakhstan, Bulgaria, Albania, } \\
\text { Turkey and Romania }\end{array}$ \\
\hline Ambil & Beverage made from fermented ragi flour, cooked rice and buttermilk. & India \\
\hline Kali & Fermented cooked rice beverage & India \\
\hline
\end{tabular}


Poor water quality was one of the leading factors for man's quest for newer beverages. Fermentation was thus employed in making various beverages primarily for their safety (Altay et al., 2013). Fermented alcoholic and nonalcoholic beverages were being made in the medieval ages. Table 1 enlists various traditional non-achoholic beverages made from fermented grains with their country of origin. Most of the grain based non-alcoholic beverages have been produced in the African and South American continents (Table 1). Some of the traditional non-alcoholic African traditional beverages include Bushera made from sorgum or millet, Kunan-Zaki made from sorghum, Mahewu made from maize, Gowé made from millets, Obiolor made from sorghum and millet and Borde made from maize, finger millet, wheat, sorghum and barley. The latter two beverages are made of multiple grains (Solange et al., 2014). Fermented nonalcoholic beverages from South America include Pozol, Agua-agria, Napú, Fubá, Acupe and Champuz. They are predominantly made from maize (Elaine Marshall, 2012). Ambil and Kali are traditional fermented beverages from India. The former is made from finger millet and latter from cooked rice. Ambil is fermented using sour buttermilk (Kumari et al., 2016).

More recently, in the last 200 years, beverages mixes made of malted grains came into being. They were meant to be consumed with milk to increase its wholesomeness and for palatability. The first malt powder was developed by William Horlick in the 1870's. In 1882, he mastered the process of drying milk alongside malt and wheat, thus making a product readily soluble in water. Doctors recommended Horlick's food to their patients (Perry, 1990).

\section{CHARACTERISTICS OF GRAINS}

\section{Barley}

Barley (Hordeum vulgare L.) is an important ancient cereal crop, first domesticated in the the Israel-Jordan region. It has been an important food source in the Middle East, northern Africa, parts of Europe and Asia. Initially, barley had been cultivated as a food crop. But as wheat was introduced and took over as a staple human food, barley was used primarily as animal fodder and for malting purposes (Sharma and Kotari, 2017). Barley grains are known to have nutraceutical properties and hence there has been a renewed interest to incorporate it in foods and exploit its benefits. Specifically, beta glucan and phenolic compounds present in barley are effective against certain health conditions like cardiovascular diseases and diabetes (Behall et al., 2004; Cavallero et al., 2002).

The use of barley as food declined during the $19^{\text {th }}$ and $20^{\text {th }}$ centuries due to the greater acceptability of rice and wheat products. With increasing scientific knowledge of the health benefits of barley seeds, especially its beta glucan, efforts have been made to improve food processing techniques to incorporate them in various foods (wheat based products noodles, cookies and extruded snack) (Newman and Newman, 2006). The Western countries use pearled barley, whole, flaked or ground in breakfast cereals, porridge, soups, stews, baby foods and bakery flour blends. In Middle Eastern and North African countries, ground pearled barley is used to make flat bread, soups and porridge (Bhatty, 1993).

\section{Oats}

A whole grain which has been gaining prominence over recent times is Oats (Avena sativa $L$.). It is particularly high in soluble fiber, $\beta$-glucan, protein, lipids and specific micronutrients, as well as appears as a unique source of polyphenols known as avenanthramides (Singh et al., 2013). Various processed forms of oats are found today which facilitate faster cooking and easier consumption. Initially, the oat grains are dehulled and scoured to obtain oat groats which are then kilned and ground, kilned, steamed and cut, or kilned, steamed and flaked to get oat flour, steel-cut oats and flaked oats respectively. Depending on the thickness of the flakes, flaked oats are further divided into rolled oats, quick oats and instant oats (Webster and Wood, 2011). A simplified flowchart of oats processing is shown in figure 3 . The main component of oat is starch and its content depends on the variety and growing conditions. Dehulled oat groats contain 15-17\% protein, 59-70\% sugars and starches, 4.5\% fat, 2-6\% b-glucan and $~ 12 \%$ dietary fiber (Usman et al., 2010).

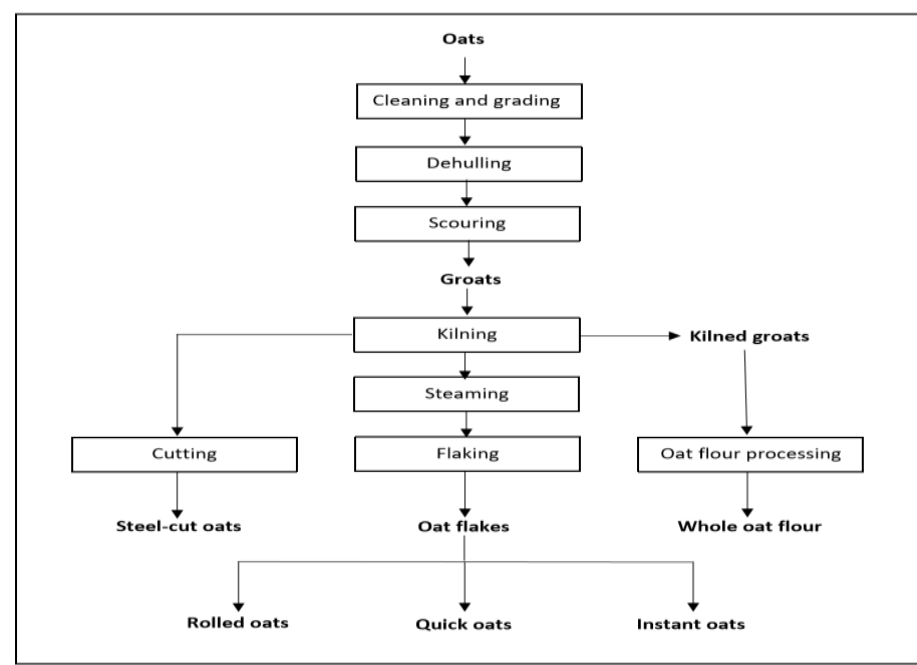

Figure 3 Oat grain processing flowchart (adapted from Webster and Wood, 2011)

Dong et al. (2015) reported an anti-obesity effect of oat dietary fiber on high-fat diet-induced obese mice. The fasting serum insulin level declined significantly $(\mathrm{P}<0.05)$ compared with model group, meanwhile, and the thyroid stimulating hormone level significantly increased $(\mathrm{P}<0.05)$, and soluble dietary fiber was more effective $(\mathrm{P}<0.05)$

\section{Buckwheat}

Buckwheat (Fagopyrum esculentum) is a pseudo cereal, origin of central and eastern European countries, and highly nutritious (Bonafaccia et al., 2003). In literature, the protein content (12\% to $18.9 \%$ ) of buckwheat grains has been reported. Starch content varies from $59-70 \%$, lipids vary from $1.5-4 \%$ and total dietary fiber is around 7\% of the dry mass (Christa and Soral-Śmietana, 2008).

Lu et al. (2013) observed significant genetic variation in buckwheat groats for 1,000-kernel weight (16.5-39.8 g). The variation found is given for the following components: total phenolic content $(6.8-20.7 \mathrm{mg}$ of $\mathrm{GA} / \mathrm{g})$, free phenolic $(4.5-$ $17.1 \mathrm{mg}$ of $\mathrm{GA} / \mathrm{g}$ ), total dietary fiber (3.6-10.6\%), insoluble dietary fiber $(2.3$ $8.6 \%)$, and soluble dietary fiber (1.4-3.4\%). Anti-inflammatory effects were attributed to the major bioactive phenolic, namely rutin and quercetin present in tartary buckwheat (Lee $\boldsymbol{e t}$ al., 2013). Buckwheat powdered sprouts (PSs) has the highest $\gamma$ - amino butyric acid (GABA) and rutin among the powdered sprouts having values of $144.7 \mathrm{mg} / 100 \mathrm{~g}$ and $768.6 \mathrm{mg} / 100 \mathrm{~g}$ respectively. Rutin-enriched buckwheat PSs significantly decreased triglycerides on day 23 of a 46 day study on SRHs (Nakamura et al., 2015). Wefers and Bunzel (2015) found large amounts of pectic polysaccharides in both buckwheat insoluble and soluble fiber.

\section{Red Rice}

Rice (Oryza sativa L.) is the chief dietary source of carbohydrates consumed by nearly one-half of the world population. There are more than 5000 varieties of rice available in the world differing in their biochemical, physical, milling and cooking qualities (Bhattacharjee et al., 2002). Among these there is a distinct group of pigmented rice which is mainly red, black and dark purple rice. Anthocyanins are the major functional components of color rice. Besides this, they contain a variety of flavones, phenolic, tannin, tocopherols, sterols, $\gamma$ oryzanols, amino acids, and essential oils (Yawadio et al., 2007). Red rice is characterized by the presence of proanthocyanidins, whereas in black rice both anthocyanins and proanthocyanidins can be present, depending on the variety (Finocchiaro et al., 2010). Besides providing color, these components deliver protective antioxidant and anti-carcinogenic activities, which help in diabetes, cardiovascular disease, and cancer prevention. According to several studies, red rice has 10 times the antioxidants of brown rice. Red rice is also mineral dense with 20 percent of the daily values for phosphorus, magnesium, and molybdenum. Red rice is known to have a pleasant nutty flavor (Ornish Living, 2017). Zaupa et al. (2015) characterized the total antioxidant capacity and (poly) phenolic compounds of differently pigmented rice varieties and their changes during domestic cooking Total phenolic acids of raw and boiled red rice were found to be $36 \mathrm{mg} / \mathrm{g}$ and $26 \mathrm{mg} / \mathrm{g}$ respectively. Total antioxidant capacity of raw and boiled red rice was found to be $43.63 \mathrm{mmol} / \mathrm{kg}$ and $20.17 \mathrm{mmol} / \mathrm{kg}$ respectively.

\section{NON-DAIRY PROBIOTIC DRINKS UTILIZING SPROUTED CEREALS, LEGUME AND SOYMILK}

A non-dairy probiotic drink using sprouted cereals, legumes and soymilk was developed by Mridula and Sharma (2014). Sprouted grain flours of wheat, barley, pearl millet and green gram were independently used to make probiotic 
drinks. The grains and green gram were soaked and then were sprouted individually. Then they were dried and milled. Then optimized amount of flours mixed with soymilk and water were fermented by Lactobacillus acidophilus NCDC14 for 8 hours. Along with these optimized amount of flours, other ingredients viz. oat, guar gum, sugar, and cardamom. All the samples were evaluated against two controls i.e. one without soymilk and other without soymilk and sugar for probiotic counts. In general, for all types of probiotic drinks, the probiotic count increased on addition of soymilk and sugar. It also increased with increasing grain flour concentration. Thus these concentrations of cereals are recommended to prepare sensory acceptable probiotic drinks. Their work has been summarized in Table 2 .

Table 2 Non-dairy probiotic drinks utilizing sprouted cereals, legume and soymilk (Mridula and Sharma, 2014)

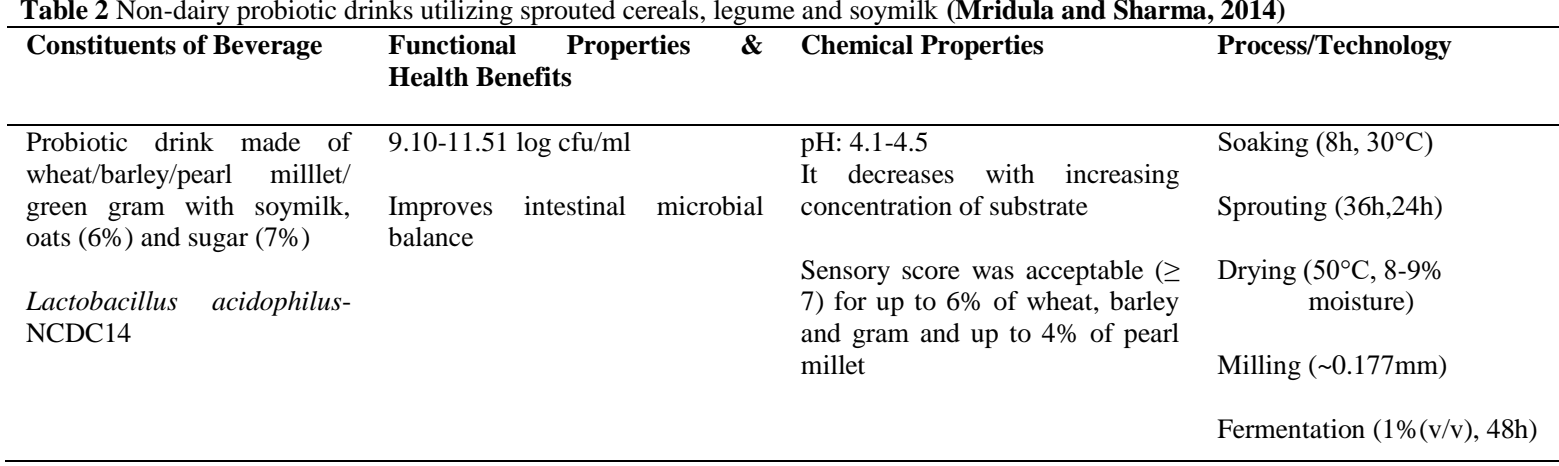

\section{Tejate: A maize-cacao beverage}

Tejate is a Mesoamerican drink prepared from maize and cocoa. The maize is nixtamalized using wood ashes traditionally. Commercially nixtamilization is done using lime. Amaro et al. (2015) studied the effect of different types of maize varieties on the nutritional quality of tejate. Tejate was prepared by mixing $3 \mathrm{~kg}$ of cuanextle-masa with $200 \mathrm{~g}$ of cacao-masa and pouring $10 \mathrm{~L}$ of iced water to it to obtain a foam-topped beverage. Cuanextle-masa is prepared by cooking $100 \mathrm{~g}$ maize together with $75 \mathrm{~g}$ wood ashes in $2 \mathrm{~L}$ of water at $90^{\circ} \mathrm{C}$ for 45 minutes, followed by rinsing, draining and coarse grinding. Cacao-masa is made by fine grinding $180 \mathrm{~g}$ cacao beans, $20 \mathrm{~g}$ rosita blossom and 10 mamey seeds which have been toasted on a hot plate for 5-10 minutes (Table 3).

Table 3 Tejate: A maize-cacao beverage

\begin{tabular}{|c|c|c|c|}
\hline $\begin{array}{l}\text { Constituents } \\
\text { Beverage }\end{array}$ & $\begin{array}{l}\text { Functional Properties } \& \\
\text { Health Benefits }\end{array}$ & Chemical Properties & Process/Technology \\
\hline $\begin{array}{l}\text { Tejate (Mesoamerican } \\
\text { drink) }\end{array}$ & GI (in vivo): $25.02-32.71$ & $\begin{array}{l}\text { Important source of } \mathrm{Cu}, \mathrm{Mg}, \mathrm{Fe}, \mathrm{Zn} \mathrm{\&} \mathrm{P} \\
\text { that met daily intake recommended }\end{array}$ & Ash nixtamalization \\
\hline Maize $(30 \%)$ & $\begin{array}{l}\text { Helps maintain normal post- } \\
\text { prandial glucose response }\end{array}$ & values (WHO/FAO 1998) & Grinding to make masa \\
\hline \multirow{2}{*}{ Cacao $(6 \%)$} & & Resistant starch (RS) & Blending with water \\
\hline & $\begin{array}{l}\text { Provides } \\
\text { micronutrients }\end{array}$ & $\begin{array}{l}0.81 \% \text { for tejapayam } \\
2.43 \% \text { for Bolitatejate } \\
\text { Starch-lipid complexes (type } 5 \text { RS) } \\
\text { formed during annealing and } \\
\text { gelatinization }\end{array}$ & \\
\hline
\end{tabular}

Tejate made by the process of ash nixtamilization had higher content of minerals $(\mathrm{Ca}, \mathrm{Fe}, \mathrm{Zn}, \mathrm{K}, \mathrm{Mg} \& \mathrm{P})$, dietary fibre and resistant starch as compared to commercially available tejate called Tejayapam. Among the local maize varieties, tejate made from White Bolita maize had the highest mineral and resistant starch content. Its properties were comparable with a commercially sold maize variety Cacahuacintle. The type 5 resistant starch present is due to the starch-lipid complexes formed during gelatinization and annealing. According to the in vitro GI studies conducted by the authors, tejate without added sugar has GI ranging from 25.02-32.71 and should be recommended to maintain the normal post-prandial blood glucose responses.

\section{Functional emmer beverages}

In this study the physical, chemical, functional, and sensory properties of nonalcoholic emmer beverages fermented with selected autochthonous lactic acid bacteria were characterized (Coda et al., 2011). Emmer flour, gelatinized emmer flour and emmer malt were used as substrates in the concentrations 5, 10, $15 \%$ for emmer malt and flour and 5, 10, 15 and 30\% for gelatinized emmer flour Based on the sensory analysis conducted and considering 7.0 as the optimal score, beverages F15, GF10, GF30 and M5 (where F, GF and M stand for flour, gelatinized flour and malt respectively) were selected for further analyses. The substrates were inoculated with $L$. plantarum $6 \mathrm{E}$ (initial cell density of ca. $5 \times$ $10^{7} \mathrm{cfu} / \mathrm{ml}$ ) to make fermented beverages. L. plantarum $6 \mathrm{E}$ and $L$. rhamnosus SP1 were used to make a probiotic beverage from gelatinized emmer flour at $30 \%$. WeisellacibariaWC9 can be used if further thickening of beverages is desired as it secretes an exopolysaccharide thus increasing the viscosity of the beverage Pasteurization was carried out for all the beverages prepared except for probiotic beverage. The paper has been summarized in Table 4 .

\begin{tabular}{|c|c|c|c|}
\hline Constituents of Beverage & $\begin{array}{l}\text { Functional Properties } \& \\
\text { Health Benefits }\end{array}$ & Chemical Properties & Process/Technology \\
\hline
\end{tabular}

\section{Haria - a rice based fermented beverage}

Haria is a rice-based fermented beverage made out of low grade boiled rice (Oryza sativa L.), belongs to West Bengal and East-Central India. Haria is known to have many health benefits. The properties and processing of Haria have been given in Table 2.5. Ghosh et al. (2014) investigated the ethno botanica importance and traditional process of haria preparation. The study was based on interactive questionnaires and laboratory experiments. Such studies can help in exploring traditional cereal based beverages and their functional properties [Table 5]. 
Table 5 Haria - rice based fermented beverage (Ghosh et al. 2014)

Constituents of Beverage $\quad$ Functional Properties \& Health
Benefits

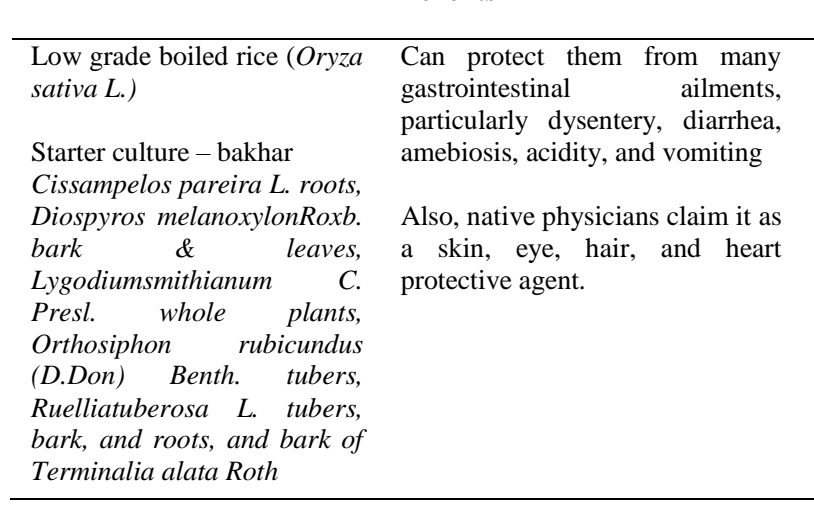

Chemical Properties

Process/Technology

$\begin{array}{ll}\begin{array}{l}\text { Contains terpene glycosides, } \\ \text { chalchone glycosides, flavanones, } \\ \text { lycopenes, }\end{array} & \begin{array}{l}\text { Fermentation in earthen } \\ \text { pot for 3-4 days. }\end{array} \\ \begin{array}{l}\text { cacopherols, } \\ \text { tocoponins, flavonoids. }\end{array} & \begin{array}{l}\text { Diluted with water and } \\ \text { filtered using fine cloth }\end{array} \\ \text { Titratable acidity: } 1.42 \% & \end{array}$

$\mathrm{pH} 3.61$

Ethanol content: $2-3 \%(\mathrm{v} / \mathrm{v})$

\section{Cereal Milks}

Plant-based milks or non-dairy milks are gaining much importance as a functional and specialty beverage across the globe. They serve as an alternative to cow's milk in a period in which lactose intolerance, cow milk allergy, calorie concern and hypercholesterolemia are prevalent. Added to this there has been a growing preference to vegan diets as well. They are also economical substitutes, where cow's milk is expensive or insufficient (Valencia-Flores, et al., 2013). A major challenge faced by cereal milks and plant-based milks in general is that they are not as nutritionally balanced as bovine and face technological challenges related to processing and preservation. Nevertheless, the functionally active components they contain and the health benefits they confer make them an attractive option. Plant-based milk alternatives are liquids that are a result of size reduction of plant material namely cereals, pseudo-cereals, legumes oilseeds and nuts, extracted in water and further homogenized to obtain a particle size distribution in range of 5-20 $\mathrm{lm}$ which imitates cow's milk in consistency and appearance (Sethi and Rahul, 2016). Optionally, small quantities of vegetable oils may be added before homogenization to increase the lipid content. Plantbased milks may be classified into the following five categories: (a) Cereal based (b) Legume based, (c) Nut based, (d) Seed based and (e) Pseudo cereal based The cereal milks that have been experimented thus far are oat milk, rice milk, spelt milk and corn milk. The quinoa milk, amaranth milk, and Teff milk were reported in the pseudo cereal category (Sethi and Rahul, 2016).

\section{CONCLUSION}

Multigrain beverages have a fine scope of being functional drinks by combining the goodness of whole grains in a liquid medium. By using multiple grains, various bioactive components get summed up in the final product and certain undesirable traits also get masked. The grains selected for the preparation of multigrain beverage in the present study are barley, oats, buckwheat and red rice The grains were selected according to their high soluble fiber and phenolic content. The presence of soluble fiber lowers the glycemic index of the beverage by slowing down its digestion and absorption, whereas phenolic compounds have antioxidant potential and scavenge the harmful free radicals in the body. In view of the work done by various researchers on cereal based beverages, it can be concluded that there are several methods that can be followed for beverage preparation and a combination of grains may be used. The beverages are primarily made with water, though milk may be used as well. Besides these, additives may be added to improve the overall quality of the beverage. The processing steps could include soaking, sprouting, malting, cooking, grinding and filtering in any suitable order. To make a fermented beverage or prebiotic, fermentation would be necessary. For non-fermented beverages, enzyme treatment may be done as well.

\section{REFERENCE}

ALTAY F., F. KARBANCIOGLU-GÜLER, C. DASKAYA-DIKMEN, and HEPERKAN, D. 2013.A review on traditional Turkish fermented non-alcoholic beverages: Microbiota, fermentation process and quality characteristics. International Journal of Food Microbiology, 167 (1), 44-56 https://doi.org/10.1016/i.ijfoodmicro.2013.06.016

AMARO D. S.-R. ROSA MARÍA GONZ? ALEZ-AMARO , JUAN DE DIOS FIGUEROA-C? ARDENAS, HUGO PERALES. 2015. Maize races on functional and nutritional quality of tejate: A maize-cacao beverage. LWT $\begin{array}{llll}\text { Food Science } & \text { and }\end{array}$ https://doi.org/10.1016/j.lwt.2015.04.015

ANDERSON J. W., P BAIRD, R. H. DAVIS, JR, S. FERRERI, M. KNUDTSON, A. KORAYM, V. WATERS, WILLIAMS, C. L. 2009. Health benefits of dietary fiber. Nutrition Reviews, 67(4), 188-205. https://doi.org/10.1111/j.1753-4887.2009.00189.x
ARYA S.S., CHAUHAN, S., SONAWANE, S. K., BALDI, B. 2013. Health benefits \& Novel uses of multigrains. Indian Food Industry Mag, 32 (4), 25-37. BEHALL K. M., D. J. SCHOLFIELD, HALLFRISCH, J. 2004. Lipids Significantly Reduced by Diets Containing Barley in Moderately Hypercholesterolemic Men. The American Journal of Clinical Nutrition, 23 (1) 55-62.

BHATTY R. 1993. Physicochemical Properties of Roller-Milled Barley Bran

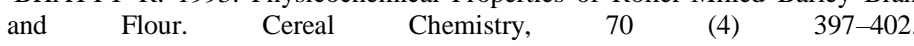
https://www.aaccnet.org/publications/cc/backissues/1993/Documents/70_397.pdf BHATTACHARJEE P., R. S. SINGHAL, KULKARNI, P. R. 2002. Basmati rice: a review. International Journal of Food Science and Technoogyl, 37 (1), 112. https://doi.org/10.1046/j.1365-2621.2002.00541.x

BONAFACCIA G., M. MAROCCHINI, AND KREFT I. 2003. Composition and technological properties of the flour and bran from common and tartary buckwheat," Food Chemistry, 80 (1), 9-15. https://doi.org/10.1016/S03088146(02)00228-5

BRENNAN, C. S. AND CLEARY, L. J. 2005. The potential use of cereal $(1 / 3,1 / 4)-b-D-g l u c a n s$ asas functional food ingredients. Journal of Cereal Science, 42, 1-13. https://doi.org/10.1016/i.jcs.2005.01.002

CAVALLERO A., S. EMPILLI, F. BRIGHENTI, AND STANCA, A. M. 2002 High (1-3,1-4)- $\beta$-Glucan Barley Fractions in Bread Making and their Effects on Human Glycemic Response. Journal of Cereal Science, 36 (1), 59-66. https://doi.org/10.1006/jcrs.2002.0454

CHRISTA K. AND SORAL-ŚMIETANA, M. 2008. Buckwheat Grains and Buckwheat Products - Nutritional and Prophylactic Value of their Components a Review. Czech Journal of Food Science, 26 (3), 153-162. https://www.agriculturejournals.cz/publicFiles/01448.pdf

CHAUHAN, S., SONAWANE, S. K., and ARYA, S. S. (2017). Nutritional Evaluation of Multigrain Khakra. Food Bioscience, 19, 80-84. https://doi.org/10.1016/j.fbio.2017.06.003

CHAVAN, M., GAT, Y., HARMALKAR, M., WAGHMAREA, R. 2018 Development of non-dairy fermented probiotic drink based on germinated and ungerminated cereals and legume. LWT, 91, 339-344 https://doi.org/10.1016/j.lwt.2018.01.070

CLEMENS, R. AND VAN KLINKEN, B. J. 2014. Oats, more than just a whole grain: an introduction. British Journal of Nutrition, 112, S1-S3 https://doi.org/10.1017/S0007114514002712

CORBO, M. R., A. BEVILACQUA, L. PETRUZZI, F. P. CASANOVA, AND SINIGAGLIA, M. 2014. Functional Beverages: The Emerging Side of Functional Foods. Comprehensive Reviews in Food Science and Food Safety, 13 (6), 1192 1206. https://doi.org/10.1111/1541-4337.12109

CODA R., C. G. RIZZELlO, A. TRANI, AND GOBBETTI, M. 2011. Manufacture and characterization of functional emmer beverages fermented by selected lactic acid bacteria. Food Microbiology, 28 (3), 526-536. https://doi.org/10.1016/j.fm.2010.11.001

DONG R.,J. ZHU, Y. LI, SHEN, L. 2015. Anti-obesity effect of oat dietary fiber on high-fat diet-induced obese mice. Journal of the Chinese Cereals and Oils Association, 30 (9), 24-29.

DYKES, L. AND ROONEY, L. W. 2007. Phenolic compounds in cereal grains and their health benefit. Cereal Foods World, 52 (3), 105-111. https://www.aaccnet.org/publications/plexus/cfw/pastissues/2007/Documents/CF W-52-3-0105.pdf

ELAINE MARSHALL D. M. 2012. Traditional fermented food and beverages for improved livelihoods. Available: http://www.fao.org/3/a-i2477e.pdf [Accessed: 06-Jul-2017].

FINOCCHIARO F., B. FERRARI, AND GIANINETTI, A. 2010.A study of biodiversity of flavonoid content in the rice caryopsis evidencing simultaneous accumulation of anthocyanins and proanthocyanidins in a black-grained genotype. Journal of Cereal Science, 51 (1), 28-34 https://doi.org/10.1016/j.jcs.2009.09.003 
FUNCTIONAL FOODS MARKET ANALYSIS By Product (Carotenoids, Dietary Fibers, Fatty Acids, Minerals, Prebiotics \& Probiotics, Vitamins), By Application, By End-Use (Sports Nutrition, Weight Management, Immunity, Digestive Health) And Segment Forecasts, 2014 T. 2016. [Online]. Available: http://www.grandviewresearch.com/industry-analysis/functional-food-market.

[Accessed: 23-Jun-2017].

GAIKWAD, S., ARYA S. S. 2018. Influence of frozen storage on quality of multigrain dough, par baked and ready to eat thalipeeth with additives. LWT, 96,350-356. https://doi.org/10.1016/j.lwt.2018.05.057

GHOSH K., C. MAITY, A. ADAK, S. K. HALDER, A. JANA, A. DAS, S. PARUA, P. K. DAS MOHAPATRA, B. R. PATI, MONDAL, K. C. 2014. Ethnic preparation of Haria, a rice-based fermented beverage, in the province of lateritic West Bengal, India. Ethnobotany Research and Applications, 12 (1), 39-49. http://dx.doi.org/10.17348/era.12.0.039-049

HARMON K 2009. Humans feasting on grains for at least 100,000 years Scientific American Blog Network. Scientific American.

HODZIC, Z., H. PASALIC, A. MEMISEVIC, M. SRABOVIC, M SALETOVIC, AND POLJAKOVIC, M. 2009. The Influence of Total Phenols Content on Antioxidant Capacity in the Whole Grain Extracts. European Journal of Scientific Research, 28 (3), 1450-216.

HÜBNER F. AND ARENDT, E. K. 2013. Germination of Cereal Grains as a Way to Improve the Nutritional Value: A Review. Critical Reviews in Food Science and Nutrition, 53 (8), 853-861. https://doi.org/10.1080/10408398.2011.562060

KUDAKE, D. C., PAWAR, A. V., MULEY, A. B., PARATE, V. R., \& TALIB, M. I. 2017. Enrichment of Wheat Flour Noodles with Oat Flour: Effect on Physical, Nutritional, Antioxidant and Sensory Properties. International Journal of Current Microbiology and Applied Sciences, 6(12), 204-213. https://doi.org/10.20546/ijcmas.2017.612.026

KUDAKE, D. C., BHALERAO, P. P., CHAUDHARI, N. S., MULEY, A. B. TALIB, M. I., \& PARATE, V. R. 2018. Fortification of Wheat Flour With Ragi Flour: Effect on Physical, Nutritional, Antioxidant and Sensory Profile of Noodles. Current Research in Nutrition and Food Science, 6(1), 165-173. http://dx.doi.org/10.12944/CRNFSJ.6.1.19

KUMARI A. A., A. PANDEY, A. RAJ, A. GUPTA, A. ROY, B. L. ATTRI, B. NEOPANY, B. MOKTAN, C.K. SUNIL, C. JANVEJA, D. RAJ, D ANGCHOK, G. MUEENUDDIN, G. VYAS, J. KABIR, K. TARGAIS, L.V.A. REDDY, S. L. MAN, AND JOSHI V. K. 2016. Cereal based indegenous non alcoholic beverages," in Indigenous Fermented Foods of South Asia, CRC Press. V. K. Joshi, Ed. 2016, pp. 353-429.

LEE C.C., S.-R. SHEN, Y.-J. LAI, AND WU, S.C. 2013. Rutin and quercetin, bioactive compounds from tartary buckwheat, prevent liver inflammatory injury. Food and Function, 4 (5), 794. https://10.1039/C3FO30389F

LU L., K. MURPHY, AND BAIK, B. 2013. Genotypic Variation in Nutritiona Composition of Buckwheat Groats and Husks. Cereal Chemistry, 509, 3-8. https://doi.org/10.1094/CCHEM-07-12-0090-R

MCKEVITH, B. 2004. Nutritional aspects of cereals. Nutrition Bulletin, 29 (2), 111-142. https://doi.org/10.1111/j.1467-3010.2004.00418.x

MORE, A.2016. Functional food market in India growing at 14-15\%; Yoghurt key trend 2016. [Online]. Available: http://www.fnbnews.com/TopNews/functional-food-market-in-india-growing-at-1415-yoghurt-key-trend39547. [Accessed: 25-Jun-2017].

MOREAU, R. A., B. D. WHITAKER, AND HICKS, K. B. 2002. Phytosterols, phytostanols, and their conjugates in foods : structural diversity, quantitative analysis , and health-promoting uses. Progress in Lipid Research, 41, 457-500. https://doi.org/10.1016/S0163-7827(02)00006-1

MRIDULA D., AND SHARMA, M. 2014. Development of non-dairy probiotic drink utilizing sprouted cereals, legume and soymilk. LWT - Food Science and Technology, 62 (1), 482- 487. https://doi.org/10.1016/j.1wt.2014.07.011

MULEY, A. B., THORAT, A. S., DALVI, S. G., TALIB, M. I., \& PARATE, V. R. (2015). Comparative studies and correlation between physicochemical and functional properties of chitosan from marine sources. Trends in Biosciences, 8(22), 6267-6274

NAKAMURA K., M. KOYAMA, R. ISHIDA, AND KITAHARA, T. 2015 Characterization of bioactive agents in five types of marketed sprouts and comparison of their antihypertensive, antihyperlipidemic, and antidiabetic effects in fructose-loaded SHRs. Journal of Food Science and Technology, 53(1), 581590. https://doi.org/10.1007/s13197-015-2048-0

NEWMAN C. W. AND NEWMAN, R. K. 2006. A Brief History of Barley Foods. Cereal Foods World, 51, 4-7.

ORNISH LIVING. 2017. "Make the Switch: Why Brown, Red and Black Rice Are Better for Your Health | HuffPost." [Online]. Available: http://www.huffingtonpost.com/ornish-living/make-the-switch-why-

brown_b_8304558.html. [Accessed: 28-Jun-2017].

PANGHAL, A., JANGHU, S. VIRKAR, K., GAT, Y., KUMAR, V., CHHIKARA, N.2018. Potential non-dairy probiotic products - A healthy approach. Food Bioscience, 21, 80- 89

PERRY C. 2017. Malted Milk: Its Cool History: Beverages: William Horlick thought he was inventing health food. Hah. - latimes 1990. [Online]. Available: http://articles.latimes.com/1990-08-30/food/fo-320_1_horlick-s-malted-milk.
[Accessed: 06-Jul-2017].

SAJILATA M. G., R. S. SINGHAL, AND KULKARNI, P. R. 2006. Resistant Starch - A Review. Comprehensive Reviews in Food Science and Food Safety, 5 (1), 1-17. https://doi.org/10.1111/j.1541-4337.2006.tb00076.x

SETHI S.AND RAHUL, S. K. T. 2016. Plant-based milk alternatives an emerging segment of functional beverages : a review. Journal of Food Science and Technology, 53(9):3408-3423. Doi: https://doi.org/10.1007/s13197-0162328-3

SHARMA P. AND KOTARI, S. L. 2017. Barley: Impact of processing on physicochemical and thermal properties - A review. Food Reviews International, 33 (4), 359-381. https://doi.org/10.1080/87559129.2016.1175009

SHARMA, P.,TRIVEDI, N., GAT, Y. 2017. Development of functional fermented whey-oat-based product using probiotic bacteria. 3 Biotech, 7: 272. https://doi.org/10.1007/s13205-017-0906-3

SINGH R., S. DE, AND BELKHEIR, A. 2013. Avena sativa (Oat), A Potential Neutraceutical and Therapeutic Agent: An Overview. Critical Reviews in Food Science and Nutrition, 53 (2) 126-144. https://doi.org/10.1080/10408398.2010.526725

SIR'O, I., E. KÁPOLNA, B. KÁPOLNA, AND LUGASI, A. 2008. Functional food. Product development, marketing and consumer acceptance-A review. Appetite, vol. 51, no. 3, pp. 456-467, 2008 https://doi.org/10.1016/j.appet.2008.05.060

SOLANGE A., K. GEORGETTE, F. GILBERT, D. K. MARCELLIN, AND BASSIROU, B. 2014. Review on African traditional cereal beverages. American Journal of Research Communication, 2 (5), 103-153.

THEBAUDINA J.Y, A.C. LEFEBVREA, M. HARRINGTONB, BOURGEOISA, C.M. 1997. Dietary fibres: Nutritional and technological interest. Trends in Food Science and Technology, 8, 41-48. https://doi.org/10.1016/S0924-2244(97)01007-8

USMAN, S., S. NAZIR, ALI, S. 2010. Determination of Biochemical Composition of Avena sativa (Oat) and to Estimate the effect of high fiber diet on hypercholesterolemic rats. BANGLADESH Res. Publ. J., 4 (4), 312-3.

VALENCIA-FLORES D. C., M. HERN?NDEZ-HERRERO, B. GUAMIS, AND FERRAGUT, V. 2013. Comparing the Effects of Ultra-High-Pressure Homogenization and Conventional Thermal Treatments on the Microbiological, Physical, and Chemical Quality of Almond Beverages. Journal of Food Science, 78 (2), E199-E205. https://doi.org/10.1111/1750-3841.12029

VALSTA, V., L. M., LEMSTROM, A., OVASKAINEN, M. L., LAMPI, A. M., TOIVO, J., KORHONEN, T., \& PIIRONEN. 2004. Estimation of plant stero and cholesterol intake in Finland: quality of new values and their effect on intake. British Journal of Nutrition, 92 (4), 671-678

WEBSTER P. J., F. H., \& WOOD, Ed., Oats: Chemistry and technology. (2nd ed.)., 2nd ed. American Association of Cereal Chemists, Inc (AACC), 2011. WEFERS D. AND BUNZEL M. 2015. Characterization of dietary fiber polysaccharides from dehulled, common buckwheat ( Fagopyrum esculentum ) seeds. Cereal Chemistry, 92 (6), 598-603.

WEISENBERGER J. 2012. Resistant Starch - This Type of Fiber Can Improve Weight Control and Insulin Sensitivity. Today's Dietit., 14 (9), 22 https://www.todaysdietitian.com/newarchives/090112p22.shtml

WOLF, A., BRAY, G.A., POPKIN, B.M. 2015. A short history of beverages and how our body treats them. Obesity Reviews 9(2):151-64 https://doi.org/10.1111/j.1467-789X.2007.00389.x

WOOTTON-BEARD, P. C. AND RYAN, L. 2011. Improving public health? The role of antioxidant-rich fruit and vegetable beverages. Food Research International, 44 (10), 3135-3148. https://doi.org/10.1016/j.foodres.2011.09.015 YAWADIO R., S. TANIMORI, and MORITA N. 2007. Identification of phenolic compounds isolated from pigmented rices and their aldose reductase inhibitory activities. Food Chemistry, 101 (4), 1616-1625. https://doi.org/10.1016/j.foodchem.2006.04.016

ZAUPA M., L. CALANI, D. DEL RIO, F. BRIGHENTI, AND PELLEGRINI, N.2015. Characterization of total antioxidant capacity and (poly)phenolic compounds of differently pigmented rice varieties and their changes during domestic cooking. Food Chemistry, 187, 338-347. https://doi.org/10.1016/j.foodchem.2015.04.055 